\title{
MULHERES E CRIAÇÃO PORNÔ-ERÓTICA: EFEITOS DA AUTORIA FEMININA NA IMPRENSA DE GÊNERO ALEGRE DA BELLE ÉPOQUE IMORAL CARIOCA*
}

Women and porn-erotic creation: effects of female authorship in the gay genre press of immoral carioca Belle Époque

Las mujeres y la creación porno erótica: efectos de la autoría femenina en la prensa del género alegre de la Belle Époque inmoral carioca

DOI: http://dx.doi.org/10.1590/S2178-14942020000200008

*Este artigo parte da tese de doutorado: CARVALHO, Marina Vieira de. Leituras do prazer: a criação pornô-erótica na alvorada da modernidade carioca. 2018. Tese (Doutorado em História) - Instituto de Filosofia e Ciências Humanas, Universidade do Estado do Rio de Janeiro, Rio de Janeiro, 2018.

Universidade Federal do Acre (UFAC) - Rio Branco (AC), Brasil.

**Profa Dra do Departamento de História (marinacarvalhohist@gmail.com).

(D) https://orcid.org/0000-0003-0139-5916

Artigo recebido em 18 de dezembro de 2019 e aprovado para publicação em 12 de abril de 2020. 


\title{
Resumo
}

A criação pornô-erótica do Rio de Janeiro no início do século XX é o tema deste estudo, especificamente, 0 aparecimento da "cortesã-cronista" na Sans Dessous e da "prostituta-educadora" no Rio Nu - periódicos pornô-eróticos repletos de marcadores de gênero masculinos. Indaga-se sobre as continuidades e transformações instauradas por essas "potências pornô-eróticas" e os significados da autoria feminina sobre leitoras e leitores, numa ordem discursiva masculina. Tais acontecimentos potencializaram deslocamentos e continuidades nas performances de gênero, tendo impacto no social-histórico aqui destacado. Buscamos acompanhar a criação de uma "sensibilidade erótica moderna" e verificar sua presença e efeitos na constituição da modernidade carioca.

PALAVRAS-CHAVE: Pornô-erotismo; Gênero; Modernidade; Imprensa; Rio de Janeiro.

\begin{abstract}
The porn-erotic creation of Rio de Janeiro in the early twentieth century is the subject of this study, specifically, the emergence of the courtesan-chronicler in the Sans Dessous and the prostitute-educator in the Rio Nu porn-erotic journals filled with male gender markers. It inquires about the continuities and transformations brought about by these porn-erotic powers and the meanings of female authorship about readers in a male discursive order. Such events have potentiated displacements and continuities in gender performances, impacting the social-historical highlighted here. We seek to accompany the creation of a modern erotic sensibility and to verify its presence and effects in the constitution of carioca modernity.
\end{abstract}

KEYWORDS: Porn-eroticism; Genre; Modernity; Press; Rio de Janeiro.

\section{RESUMEN}

La creación erótica porno de Río de Janeiro a principios del siglo XX es el tema de este estudio, específicamente, la aparición de la cortesana-cronista en Sans Dessous y la prostituta-educadora en Rio Nu — revistas porno eróticas llenas de marcadores de género masculino. Se indaga sobre las continuidades y transformaciones introducidas por estos poderes porno-eróticos y los significados de la autoría femenina sobre lectores masculinos y femeninos, en un orden discursivo masculino. Tales eventos potenciaron cambios y continuidades en las actuaciones de género, teniendo un impacto en la historia social histórica resaltada aquí. Buscamos acompañar la creación de una sensibilidad erótica moderna y verificar su presencia y sus efectos en la constitución de la modernidad en Río.

PALABRAS CLAVES: Pornoerotismo; Género; Modernidad; Prensa; Rio de Janeiro. 


\section{INTRODUÇÃO}

nsia. Quando decidi o tema do meu doutorado, acreditava que estudar a sexualidade
me abriria um mundo de transgressões. Fui em busca da documentação na qual encontraria a mobilização das dimensões pornô-eróticas ${ }^{1}$ da existência no período histórico a que dedico os meus estudos, a Primeira República brasileira. Descobri dois periódicos que me instigaram: o jornal Rio Nu (1898-1916) e a revista Sans Dessous (1909-1910). Nessa documentação, encontrei, sim, normatividades - como a presença do discurso ${ }^{2}$ médico, as teorias de branqueamento atreladas à noção de progresso e civilização —, mas também encontrei transgressões - à política da Primeira República, à moralidade católico-portuguesa. Sendo assim, esta pesquisa afirma que o pornô-erotismo do início do século XX não foi apenas uma reprodução dos discursos cientificistas, racistas, machistas e classistas; ele foi isso e muito mais. No entanto, algo continuou me incomodando.

0 "vigor feminino" em que lugar estaria? Ao perscrutar os jornais de gênero alegre (como eram chamados os periódicos considerados pornográficos), deparo-me com a intensa e constante objetificação da mulher. Neles, as mulheres são celebradas, temidas, desejadas, criticadas, porém não como sujeito de sua sexualidade e de sua criação artística, filosófica, literária. Elas aparecem pela verve masculina, pela mobilização dos imaginários do iluminismo libertino ${ }^{3}$ e da natureza da mulher oitocentista ${ }^{4}$. Isto é: ou são belas, recatadas e do lar; ou são histéricas, diabólicas e fatais. Onde estariam as mulheres criadoras de produções literárias, artísticas e jornalísticas que tematizassem a dimensão erótica da existência? Como toda obviedade histórica é, em si, uma sofisticada tecnologia de poder, não me conformei com tal situação e passei a investigar possíveis criações pornô-eróticas de mulheres na Primeira República. Para minha surpresa e prazer, encontrei expressões na literatura e na poesia. E mais: encontrei também voz autoral feminina tanto na Sans Dessous como no Rio Nu: respectivamente, Germaine e Greda Pataka. É sobre essas duas colunas que se dedicam as próximas páginas.

Ambivalências ${ }^{5}$. Ao lê-las, uma questão apresentou-se: seriam Germaine e Greda Pataka personagens históricas "reais" - isto é, mulheres que de fato escreveram para o Rio Nu e a Sans Dessous — ou seriam os próprios redatores dos periódicos — de escrita pornô-erótica repleta de marcadores de gênero masculino - que resolveram escrever como se fossem muIheres "reais", adotando em suas escritas possíveis idiossincrasias femininas?

A produção pornô-erótica da Belle Époque ${ }^{6}$ imoral só se torna possível pelas transformações nos meios materiais que o capitalismo promoveu (Hunt, 1999) — técnicas de reprodução em série, mercado editorial, consumo em massa, porém os efeitos de suas potências nos sujeitos não se encontram nas ruas, nas casas ou em qualquer lugar que nosso empirismo 
possa identificar e demarcar; eles se realizam num espaço por excelência subjetivo: em nossa imaginação.

Por isso, destaco nestas páginas os movimentos entre realidade, imaginação e ficção, pois é nessa relação que as produções pornô-eróticas mostram a potência de sua transgressividade ao social-histórico estabelecido. Tais fontes são aqui entendidas como um conjunto narrativo extenso, cada qual com sua presença-diferença compreendida pela noção de ficcionalidade de Wolfgang Iser (2013). 0 autor substitui a dicotomia tradicional entre real e ficção pela tríade "realidade", fictício e imaginário7. Para Iser (2013), as ficções configuram e manifestam o(s) imaginário(s), permitindo assim sua investigação. Imaginário e real são partes constitutivas do ficcional aqui destacado. Autores e autoras partem de determinadas situações sociais, sem se esgotar nelas, para aumentar seu poder de convencimento. Ou seja, a narrativa pornô-erótica ativa o jogo do "como se" 8 ficcional — jogo que se expande justamente na interação fictício/imaginário e em seus graus de ultrapassagem da realidade. 0 objetivo não é fazer crítica literária ou plástica, dada a natureza diversa das fontes e também o local de fala ${ }^{9}$ deste estudo - a história. No entanto, foi necessário abraçar essa diversidade e cruzar fronteiras disciplinares, pois ela compõe os enunciados, no dizer de Foucault (2009) ${ }^{10}$, do pornô-erotismo em questão. Ordens discursivas marginais aos cânones, as quais não "deveriam" existir, mas existiram e afetaram e foram afetadas pelo social-histórico do período.

O pornô-erotismo pode ser assim entendido como uma manifestação originada pela interação entre real e imaginário operada pela criação ficcional, sendo os jornais de gênero alegre um de seus produtos. Dessa forma, a autenticidade ou não da "real" existência de Germaine e Greda Pataka não é a problemática deste estudo, pois o que interessa aqui são os efeitos produzidos pelas ficções pornô-eróticas no Rio de Janeiro no limiar de sua modernidade, bem como os significados do aparecimento de escritas pornô-eróticas de verve feminina no Rio Nu e na Sans Dessous, periódicos repletos de marcadores de gênero masculinos. Tais criações nos indicam deslocamentos e continuidades nas performances de gênero ${ }^{11}$, tendo impacto no período aqui destacado. A pesquisa busca acompanhar a criação de uma sensibilidade erótica moderna ${ }^{12}$ e verificar sua presença e seus efeitos na constituição da alvorada da modernidade ${ }^{13}$ carioca.

\section{ESCRITAS DE REVOLTA:}

\section{SANS DESSOUS E A CORTESÃ-CRONISTA}

$\int_{\text {sofisticação instaurada pela modernização da imprensa. Direcionando-se a um público }}$ favorecido socioeconomicamente, a revista propunha-se a ficcionalizar um pornô-erotismo 
elegante, de modo que fortalecesse a identificação do Brasil com as "modernas civilizações ocidentais", mais precisamente, com Paris. Seu design era moldado nos novos padrões artísticos e literários do fin de siècle, principalmente o art nouveau e o simbolismo (Carvalho, 2018: 258-297), celebrando a Belle Époque imoral na capital do país. "Carnet de uma mundana" era uma de suas colunas, assinada por Germaine - uma prostituta de alto luxo cujo nome apareceu em algumas edições da revista como uma das do concurso: "Das nossas 'demi mondaines'14 qual é a mais bonita?" (Concurso..., 1909: 16). Concurso em que concorriam profissionais do sexo dos requintados rendez-vous da cidade, sendo esta uma das principais características da revista: a relação direta com as profissionais do sexo. As prostitutas de alto meretrício tornavam-se grandes celebridades na revista. Elas estavam presentes de diversas formas: mandavam cartas, participavam de concursos de beleza, eram fotografadas pelas ruas do centro da cidade e nos cabarés de alto luxo. Relação que explica a vida breve da revista, pois, apesar das estratégias editoriais, a Sans Dessous não conseguiu rechaçar a acusação de fazer propaganda da prostituição (Carvalho, 2018: 326).

Germaine teria recebido 3.180 votos — número que pode ter sido aumentado como uma demonstração de popularidade da revista. Mesmo com essa quantidade expressiva, não ganhou o concurso. Caso tivesse, conheceríamos o seu rosto, pois a vencedora, Marthe Drufrène, recebeu uma medalha de ouro e teve sua foto publicada como a mais bela da cidade. De todo modo, "Carrnet de uma mundana" é uma coluna cuja escrita apresenta, em primeira pessoa, as idiossincrasias de uma prostituta famosa de um elegante cabaré da cidade, de clientela formada por homens das camadas socioeconomicamente privilegiadas da capital do país. Nesse espaço, ocorre uma "torção" em relação aos papéis tradicionais de gênero feminino - a mulher tradicionalmente objetificada nas ficções pornô-eróticas ascende à condição de sujeito. Aqui também outra relação se inverte: é a prostituta que vira cronista e nos informa sobre a Belle Époque imoral carioca ${ }^{15}$. A coluna vinha complementada com a Figura 1.

"O que distinguia uma mulher da elite carioca de uma coquete francesa era sua apresentação pública. [...] Quando uma mulher virtuosa saía na rua, não poderia aparecer nenhum indício de cocote nela. Os estilos das cocotes eram muito bem conhecidos" (Green, 2004: 15). $\mathrm{Na}$ ilustração, vemos o corpo branco e sinuoso, com cintura marcada para melhor apreciação de suas formas, volumosas nádegas e, pela "levantadinha" que dá em seu vestido, as pernas destacam-se, lembrando, assim, as dançarinas de cancã; cabeça um tanto inclinada para encarar o leitor, com um sorriso malicioso no canto da boca, chapéu orgânico bem ao gosto art nouveau. Aqui chegamos a outro elemento rico em significados sobre a relação entre a criação pornô-erótica e a construção da modernidade. As potências pornô-eróticas masculinas da Belle Époque imoral carioca constroem um tipo ficcional de feminino, o qual nomeio de 


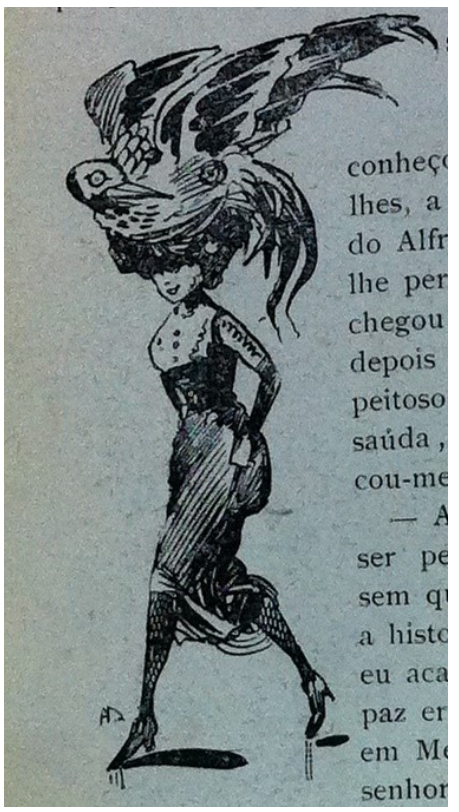

Figura 1 - "Carnet de uma mundana". Fonte: Germaine (1910a).

gentrificado ${ }^{16}$ pelos objetivos e usos que essa forma de representação exerceu em seu tempo. Isto é, a imprensa de gênero alegre criou e celebrou um tipo de feminino que é chamado nesse estudo de gentrificado por edificar o corpo da mulher do desejo como "signo" e "símbolo" da modernização do país, numa relação em que espaço e gênero se instituem instituindo um ao outro simultaneamente ${ }^{17}$, proporcionando a materialização do imaginário da Belle Époque imoral. Nessas potências pornô-eróticas:

As repetições das performances de gênero masculina e feminina, articuladas com o imaginário da civilização orientado pela ficção pornô-erótica, institui instituindo um erotismo moderno. Noção que leva em consideração categorias como cor, classe, sexualidade e regionalidade, as quais são selecionadas e combinadas para produção dessa ficção. A muIher gentrificada tem uma determinada cor (branca), classe (média e burguesa), sexualidade (heterossexual e, às vezes, homossexual para o voyeurismo masculino) e regionalidade (a carioca urbana à luz da francesa). As ficções pornô-eróticas masculinas, que faziam sucesso pelo tema e por trabalharem com o horizonte de expectativas de grande parte de seu público, institui instituindo um social-histórico no qual se nega a desigualdade social, a herança colonial e escravista; possibilitando a imaginação de outro feminino - gentrificado, repita-se -, o qual é celebrado como marca da modernidade carioca. Assim almejavam difundir a imagem de uma cidade branca, socioeconomicamente abastada e imoralmente 
civilizada, configurando a colonização do desejo dessa masculinidade (Carvalho, 2020: 14-15, grifo do autor) $)^{18}$.

Em "Carnet de uma mundana", a composição do feminino gentrificado apresenta uma diferença que inverte a tradicional objetificação da mulher do desejo pornô-erótico: é a cocote quem apresenta o inverso de todo conteúdo da revista, relatando as experiências, sensações e impressões de uma prostituta de alto meretrício sobre seu trabalho, seus clientes, sua vida. Aqui, acompanharemos o carnaval de 1910 por meio de nossa "cortesã-cronista":

Depois que deixei o sossego honesto da família e atirei às ortigas a responsabilidade pesada do nome solene de meu marido, foi este o primeiro Carnaval que assisti.

E em que dificuldade me encontro para detalhar aqui as impressões que me deixou essa balbúrdia de loucuras e folias.

Pela primeira vez, num rasgo heroico de ousadia, apareci em público quase nua, pois nem era outro esse leve disfarce em que me meti, de um maillot completo, velado apenas pela transparência perturbadora de uma gaze branca e paillettée.

Na intimidade de meu boudoir, diante da franqueza leal do meu espelho grande, achei-me perturbadora.

0 maillot é a quintessência da provocação. Todas as linhas das minhas formas tinham um detalhe insolente e ousado. Percebi logo a extensão do meu sucesso (Germaine, 1910b: 14).

0 texto inicia-se com uma nostalgia que produz uma positivação do "sossego honesto da família". A esposa, rainha do lar, em contraposição à prostituta, que tem um lugar destacado na cena masculina. Dicotomia usual na discursividade pornô moderna masculinista, a qual a irrupção de escritas pornô-eróticas de mulheres transgride por libertar o feminino de tais polos opositores, destacando seus conflitos e desejos, entre eles a mulher como sujeito erótico. Seria Germaine uma personagem inventada pelos redatores da Sans Dessous? Se sim, sua escrita relaciona-se com a ordem discursiva masculina, a qual inclui a culpa e a vergonha pela licenciosidade. A fala de Germaine pode ser uma expressão desse desejo de reabilitação dos homens, via expiação das mulheres prostitutas. Senão, sua escrita expressa dilemas e conflitos de mulheres divididas entre a ânsia por liberdade e um ordenamento social que almeja aprisioná-las ou no lar ou nos prostíbulos.

Primeiro carnaval "livre" de Germaine, sem o domínio do marido e a vigilância social de uma mulher "honesta". Ao sonhar com o carnaval, ela se produz minuciosamente para a "festa da carne"! Diante do espelho, a demi-monde admira-se, acha-se linda e encantadora com seu maillot. Pela descrição de sua vestimenta, Germaine poderia estar usando uma fantasia como a da Figura 2. 


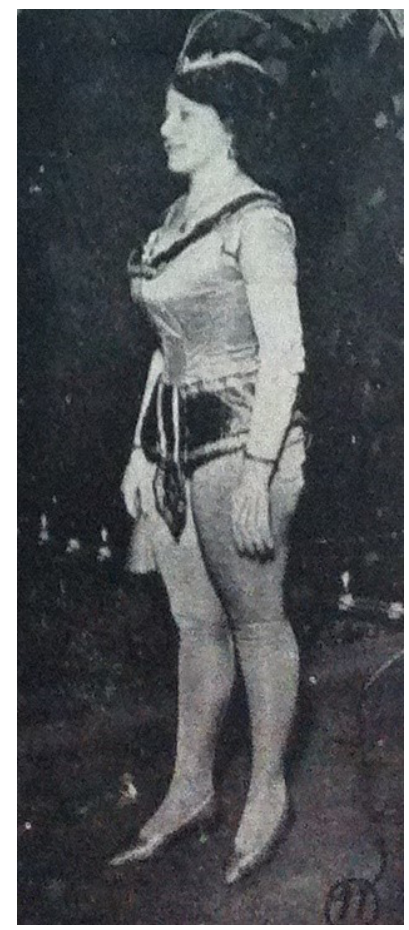

Figura 2 - High Life Club. Fonte: "High Life Club" (1910).

Essa foto foi tirada pela "Kodack Sans Dessous" no carnaval do High Life Club ${ }^{19}$ de 1910, frequentado pelos homens da alta sociedade. Acompanhados de suas cocotes, eles fugiam da câmara da Sans Dessous ou, quando posavam para foto, cobriam-se nos disfarces de suas fantasias. A crônica apresenta o carnaval de 1910 pela verve de uma profissional do sexo. Germaine, sentindo-se magnífica com seu maillot, "num rasgo heroico de ousadia", aparece "em público quase nua":

Quando o meu amável deputado apareceu-me no disfarce fúnebre do seu dominó negro a primeira sensação que tive foi de... pudor e vergonha. Ele fez-me a apoteose de sua admiração, em frases de uma velha retórica pesada, não esquecendo até a velha comparação que me irmanava a Frinéia e ao velho bando de cortesãs romanas. Estava simplesmente detestável, o meu deputado.

No baile, redobrou aquela sensação de pudor e vergonha... Vinha a tempo, não há dúvida. Era a primeira vez que eu expunha à contemplação basbaque dos homens, a perfeita conformação do meu corpo. E durante toda a noite, tive a seguir-me um cortejo insuportável de admiradores. Muitos suplicavam-me a designação do meu nome e da minha residência. 
Outros mais ousados, batiam-me nas coxas e nos braços para se certificarem de que eram meus mesmo.

Através do loup de veludo negro, corei diversas vezes ao ouvir a irreverência de certas exclamações. A meu lado, fúnebre e calado, no seu dominó de seda preta, o meu deputado, velava-me gozando, naturalmente, o meu extraordinário triunfo.

Ganhei o primeiro prêmio de elegância e beleza, oferecida pelo Club. Não sei porque, sinto-me triste em rememorar os sucessos daquela noite.

A vida é assim.

0 gozo e a alegria só são perfeitas quando proibidas e veladas.

Quando chegamos a casa, pela madrugada, o meu deputado, na sua terrível exibição retórica, comparou-me à Suzana no banho.

Desesperei e pu-lo pela porta fora.

Que imbecil! (Germaine, 1910b: 14, grifos da autora).

Pelas datas das publicações do "Carnet de uma mundana", o deputado que a acompanhou no carnaval talvez seja o seu vieux marcheur ${ }^{20}$, descrito em crônicas anteriores como um idoso de posses e prestígio que exigia fidelidade da "sua" prostituta, o que é mais uma característica dessa masculinidade encontrada nos jornais de gênero alegre, principalmente nas colunas do Rio Nu dedicadas aos prostíbulos e às prostitutas da cidade. Germaine, após se produzir como nunca para vivenciar pela primeira vez "livremente" o carnaval, encontra seu velho deputado no "disfarce fúnebre do seu dominó negro", fantasia muito popular naquele carnaval, conforme as fotos da Sans Dessous, na qual não se pode ver o rosto nem grande parte do corpo da pessoa, ótima para tais senhores acompanharem as "suas cocotes" num quase anonimato. Ao encontrá-lo, as primeiras sensações que Germaine teve foram pudor e vergonha, o que se relaciona com o imaginário sobre a natureza do feminino moderna ${ }^{21}$, marcado pelo recato, o qual era e ainda é mobilizado pelo social-histórico do Rio de Janeiro que institui instituindo homens e mulheres. Ao encontrá-la, o deputado começa "uma velha retórica pesada" sobre cortesãs. Visualizando a cena: ela, mulher jovem e sedutora, repleta de expectativas para o seu primeiro carnaval sem a tutela de seu ex-marido, é vigiada o tempo inteiro por um velho deputado, disfarçado de dominó, "fúnebre e calado" e que nada faz em relação aos assédios sofridos por Germaine; ao contrário, ele vela-a "gozando, naturalmente", de seu "extraordinário triunfo". Para piorar, ele começa a contar histórias de cortesãs da Antiguidade ocidental — erudição eurocentrada característica de muitos dos deputados idosos da Primeira República. A reação dificilmente seria outra: "Estava simplesmente detestável, o meu deputado". Sua vergonha e pudor tornam-se mais fortes quando chega ao baile, pois é a primeira vez que ela expõe "à contemplação basbaque dos homens" o seu corpo seminu, para a época. 
Germaine apresenta diversas modalidades de assédios: "um cortejo insuportável de admiradores", os quais inquiriam seu nome e endereço; registra que chegara a corar "diversas vezes ao ouvir a irreverência de certas exclamações". Não só ataques verbais ela relata, mas físicos também: "batiam-me nas coxas e nos braços para se certificarem de que eram meus mesmo". Todos esses ataques foram acompanhados por seu vieux marcheur, que se envaidecia por possuir o objeto de cobiça dos homens do baile. Para fechar sua noite de carnaval, quando ela tomava banho, seu velho deputado a comparou a Suzana Castera - ex-dançarina do Alcazar Lyrique e proprietária de um requintado cabaré na Praia do Flamengo, onde figurões da política debatiam questões da nossa recém-nascida república entre champanhes e cocottes $^{22}$. Sendo assim, mesmo tendo conquistado o prêmio de beleza e elegância, pois ela materializou o "feminino gentrificado" celebrado por tal masculinidade, Germaine não conseguiu se alegrar ao lembrar-se daquela noite. Suas lembranças encheram-na de tristeza, fazendo-a suspirar: "a vida é assim". 0 episódio, ficcional ou não, sinaliza a permanência de uma ordem discursiva, pois a exposição do corpo feminino parece ainda "autorizar" a cobiça, o desrespeito, o assédio, a violência. Uma "tradição histórica" que Germaine, "num rasgo heroico de ousadia", enfrentou, corporificando quase um século antes a frase atual "meu corpo, minhas regras". 0 desfecho da noite de Germaine indica-nos os custos emocionais da iniciativa libertária da nossa prostituta-cronista.

Ao criar uma coluna assinada por uma suposta profissional do sexo, a revista abre espaço para uma "escrita de revolta", na qual idiossincrasias das prostitutas de luxo, seus sentimentos, pensamentos e sensações formavam a verve de crônicas de uma revista em que a maioria dos leitores eram os clientes dos cabarés elegantes do período. Talvez fosse uma forma não só de denúncia, catarse, mas também certa vingança ao apresentar a essa masculinidade o que uma prostituta sentia por seus clientes, além de ser um alerta, um apelo moralista e regenerativo, para jovens, como Germaine, que sonhavam com a liberdade e independência que imaginavam ter as profissionais do sexo.

Encontrei-o pela primeira vez no recinto elegante dos "Bohêmios".

Falamo-nos com a cerimônia natural dos que se encontram pela primeira vez, embora, lá fora, se pense, que nos destinos de nossa vida alegre, a cerimônia não passa de uma figura de retórica.

Falamo-nos. Disse que era escritor e citou-me os nomes de seus livros publicados. Desta noite e diante, unimo-nos em uma camaradagem de palestras. Pareceu-me, a princípio, rapaz de independências dinheirosas e largas consagrações no meio literário.

Cheguei a admirá-lo, por momentos, embora o achasse pançudo demais para a idade que aparentava e me parecesse inexpressiva demais a fisionomia, para o talento que proclamava. 
Fazia-se elegante nos modos e na "toillete" e para não falar as regras ensinadas pela Europa culta, trazia ao olho, a roda de um monóculo imponente e ousado. Em todo o caso, apreciava-o, talvez por ser a primeira vez que encontrava no rumo desta difícil vida alegre, alguém com um pouco de verniz intelectual. Fez-me a corte. Aceitei-a. E todos os dias, à hora certa, recebia eu, de envolta com o derretimento de frases madrigalescas, um lindo bouquet de rosas frescas. Isto durou uma semana. À noite, encontrávamo-nos no club elegante e palestrávamos.

Mas não passávamos daí. Um dia desapareceu. E hoje, com surpresa, recebi a conta de um florista. Eram as lindas rosas que ele me mandava durante toda uma semana.

Paguei e assim, pela primeira vez, tive eu que pagar as flores que me ofereciam.

Felizmente, foram só flores. Entretanto, quem o ouvisse falar, julgá-lo-ia possuidor de dinheiro farto e independências elegantes.

Pois sim! (Germaine, 1910c: 14).

Aqui, duas "existências-performances" chocam-se: o "feminino gentrificado" das potências pornô-eróticas masculinas e a do Dândi/Pelintra dos elegantes clubes e cafés da Belle Époque. 0 jovem encontra-a no elegante club Bohêmios e faz o ritual de cerimônia da primeira impressão. Diz que é escritor, fala de seus supostos livros publicados, o que a faz pensar que se trata de "rapaz de independências dinheirosas e largas consagrações no meio literário". Isso porque sua performance é minuciosamente apresentada, não só por seus dotes literários, mas também pela forma como se veste e pela erudição que "aparenta" ter. Como resistir a essa performance em meio ao dandismo $0^{23}$ da Belle Époque carioca? "A aparência é, em si, o jogo constitutivo de uma identidade pontual que existe porque se relaciona com o outro e com as condições culturais e históricas que a cercam" (Dealtry, 2009: 43).

No imaginário pornô-erótico da "cidade espetáculo", para seduzir uma mulher, principalmente uma "mulher gentrificada" como Germaine (branca, refinada, afrancesada), era preciso ser visto, apreciado: "encontrávamo-nos no club elegante e palestrávamos". Até que, em um nada belo dia, ele sumiu, e quem apareceu? Um florista com a conta das lindas rosas frescas que o jovem galante enviara por uma semana. Nesse "jogo de máscaras", a verdade não está em sua "verdadeira essência", e sim na performance de sua aparência. Ambas eram atuações com objetivo de conquistas pessoais. Para Germaine, seria um cliente endinheirado, culto e elegante com o qual, além de ganhos econômicos, desfrutaria de uma agradável companhia refinada e, ainda, aumentaria seu prestígio social. Para o jovem, já que ele não chegou a desfrutar dos prazeres sexuais que teria com a demi-monde, qual seria a vantagem? Desfilar nos salões da Belle Époque carioca em companhia de uma mulher símbolo e signo da modernização imoral. A performance social do pseudoescritor ampara-se em um dos tipos sociais em moda no início do século XX, atuante também nas escritas pornô-eróticas dos periódicos de gênero alegre: o "pelintra" — homem jovem que tem por estratégia de ascensão 
social o cuidado em "parecer" refinado e erudito, o zelo com suas vestimentas e acessórios elegantes (Carvalho, 2018: 298-313). 0 importante em sua tática não era o fato de ter um relacionamento com ela - até porque ele não teria o dinheiro necessário para tal relacionamento - ; o que importava era figurar ao lado desse feminino gentrificado e aumentar assim seu capital simbólico, o que poderia lhe render possíveis ganhos socioeconômicos nesse jogo de aparências que compõe a sensibilidade do período finissecular.

Uma das qualidades mais apreciáveis desta nossa agitada vida alegre é, incontestavelmente, o segredo profissional. [...] Entretanto, ainda há por aí muito espírito bobo que mete a bulha e ridiculariza a discrição da mulher.

Tolos! Se não fosse o critério da nossa discrição, que triste vida de desilusão e de surpresas seria a da humanidade. [...] se nos descêssemos ao prazer de desvendar, bem tristemente devia exibir a nossa admiração e figura submissa o humilde desse brutamontes solene que se chama Homem.

Neste curto prazo de tempo do meu tirocínio de vida alegre, quanto segredo intimamente familiar, tenho conhecido e ouvido, quanto!

0 homem é sempre um submisso diante da mulher no momento em que vai possuí-la. E é ele mesmo que procura externar essa mesma submissão clássica, por todas as formas que the possam parecer denunciadoras da mais exata e patente humildade.

Ah! a risível situação do Homem diante da majestade sensual da mulher que deseja!

Nesses momentos terríveis, há como que uma transformação instintiva em todos os sentidos e um rebaixamento inacreditável de todas as qualidades e eles o que pretendem apenas é a exteriorização de sua sensualidade, alguns pelo ameigamento da voz, outros pelos disparates das mais incongruentes atitudes carinhosas.

Este, por exemplo que daqui saiu, ainda há pouco, é lá fora, o tipo de homem elegante e fino, de nome respeitado e mérito proclamado. Citam-no como exemplo da espécie de maridos corretos e dos chefes de família modelos.

Entretanto... Se rompendo as exigências do meu segredo profissional, eu denunciasse aqui o feito de seu carinho animal, a humildade de sua atitude, que pasmo, que surpresa provocaria a minha denúncia.

Simplesmente porco! (Germaine, 1910a: 8).

Germaine, nessa crônica, apropria-se do imaginário pornô-erótico masculino tão divulgado pela Sans Dessous e descreve, em minúcias, o que uma femme fatale sente ao fazer sexo com esse "exemplar" de masculinidade. Nossa cortesã-cronista apresenta outra masculinidade: o "Homem" — viril, elegante, bem-sucedido, respeitado, pai e chefe de família exemplar — tem seu "semblante ${ }^{24}$ desfigurado" pela "escrita de revolta" dessa "mulher fatal". Ela apropria-se de uma "feminilidade objetificada, mercantilizada, construída para despertar um 
espetáculo atraente, erótico, centrado no fetiche" (Oliveira, 2005: 14) para desconstruir, em sua escrita, o domínio do macho-patriarcal. Se a cocotte é a presa de uma ficção pornô-erótica masculina, Germaine inverte esse jogo, sendo essa uma característica das escritas pornô-eróticas de francesas decadentistas ${ }^{25}$.

"Carnet de uma mundana": uma "escrita de revolta" de gênero feminino no interior do pornô-erotismo masculino. Por meio das crônicas de Germaine, podemos chegar a outras dimensões do "feminino gentrificado", para além de sua objetificação — as formas como a desejam, como se relacionam com ela, como ela deveria se comportar. Germaine transgride a ordem desse discurso ao apresentar o cotidiano dos prostíbulos de luxo da capital do país por meio das experiências, impressões e sensações de uma "mulher-prostituta-cronista". Essa masculinidade, consumidora e objetificadora de seu corpo e existência, ao ler sua coluna, vê-se atacada, agredida, humilhada, desfigurada por sua "mulher do desejo".

\section{EDUCAÇÃO SEXUAL E ORIENTAÇÃO PROFISSIONAL: O RIO NU E A PROSTITUTA-EDUCADORA}

$\mathrm{D}$ iferentemente de outros jornais de gênero alegre, o Rio Nu teve vida longa, circulou de 1898 a 1916, tornando-se uma espécie de modelo para os demais jornais pornô-eróticos que surgiram nas primeiras décadas do século XX. Enquanto a Sans Dessous se direcionava apenas aos setores socioeconomicamente privilegiados e às prostitutas de alto meretrício, o Rio Nu operava com um público mais amplo e diverso, dialogando com pessoas de diferentes classes sociais, composições étnico-raciais e idades, e, surpreendentemente, não foi "a primeira publicação da imprensa brasileira destinada exclusivamente ao público masculino" (Ferreira, 2015: 119, grifo meu). No Rio Nu, encontrei outra coluna com voz autoral de mulher-prostituta: "Consultório Feminino", assinada por Greda Pataka. As estratégias de escrita da coluna produzem uma narrativa em que Pataka seria uma prostituta com uma grande rede de sociabilidade no mundo da prostituição da cidade, a qual aconselhava as leitoras do jornal respondendo as cartas que enviavam para a redação. "Consultório Feminino" foi lançada no último ano do Rio Nu, o que indica uma conquista de espaço de escritas pornô-eróticas de verve feminina, uma novidade, uma efetiva diferença na ordem discursiva masculina praticada pelo periódico. Talvez a literatura erótica de Gilka Machado e Albertina Bertha, publicadas na época, tenha favorecido tal acontecimento, pois seus livros foram sucesso de vendas pela curiosidade e polêmica que provocavam (Carvalho, 2018: 133-182); o que o Rio Nu pode ter aproveitado para atrair leitores e leitoras. Acontecimentos que indicam também o aumento da importância das mulheres como público do periódico, pois só encontramos respostas de cartas assinadas por mulhe- 
res. Ou seja, uma coluna construída para ser de "mulher para mulher" na discursividade pornô-erótica masculina, produzindo o espaço de algum desvio na fala dominante. Quais os significados dessa diferença?

"Consultório feminino" é uma cartilha de orientação profissional para prostitutas, o que confirma a relação direta entre os redatores do jornal e as áreas de meretrício da cidade, principalmente dos bairros do centro e zona sul do Rio de Janeiro. Muitas prostitutas enviavam cartas ao "Consultório Feminino". Algumas perguntavam a Greda como conseguir o que desejam de seus "maridinhos" - forma como Greda chamava os clientes fixos das profissionais do sexo, os quais, por um lado, eram desejados por elas, pois representavam a garantia de uma renda fixa, por outro exigiam fidelidade e submissão de suas prostitutas preferidas, o que ocasionava diversos e constantes conflitos e disputas entre cortesãs, proprietários de prostíbulos e clientes (Carvalho, 2018: 340-348). Para seduzir e conquistar possíveis "maridinhos", as profissionais do sexo recorriam ao "Consultório Feminino" em busca dos conselhos de nossa "prostituta-educadora":

Sebastiana - o melhor meio de conseguir tudo de seu maridinho é negar-lhe a ração quando ele não andar direitinho. Conta-se que a célebre Marquesa de Santos assim procedia com nosso primeiro Imperador: apanhando-o maluco trancava-se no quarto, com as vestes dos selvagens e exigia que o monarca passasse por baixo da porta tudo o que ela queria - atos de nomeações, decreto de favores, tudo. Depois é que então abria satisfeita a porta. Abria-lhe a porta e mais alguma coisa e ele entrava, não como rei, mas como qualquer camarada faminto (Pataka, 1916a: 2).

Aqui a erudição é mobilizada pela potência pornô-erótica de Greda, cuja estratégia de sedução se ampara no conhecimento da história do Brasil, filiando-se à linhagem de uma das amantes brasileiras mais conhecidas: a Marquesa de Santos. 0 argumento é consistente, pois muitos desses "maridinhos" eram políticos da República brasileira. E quando o cliente não era um bom maridinho? "Sylvia S. - fuja do perigo enquanto puder. Sempre que o primeiro brejeiro chorar as suas misérias é preferível a menina abrir o olho do que perder o que não deve. Escreva, quando quiser e apareça mesmo, se tiver vontade" (Pataka, 1916b: 3). A orientação narrativa indica que Sylvia S. estaria no início de carreira na "difícil vida alegre", recorrendo à orientação de uma profissional do sexo experiente, a qual, além de aconselhá-la, incentiva que sempre a procure, não só por cartas, e assegura que, se tiver vontade (necessidade), pode mesmo ir ao seu encontro. Em outra passagem, a resposta de Greda orienta as leitoras e os leitores a concluírem que seus domicílios eram conhecidos pelas profissionais do sexo da cidade, como no seguinte aconselhamento: "Antônica — Veja se consegue trazer o seu maridinho a nossa presença. É possível que o que está procedendo seja por falta de prática 
da menina. Se assim for, com três lições que lhe daremos com a sua presença ele ficará mais dócil" (Pataka, 1916c: 7).

A escrita apela para a suposta experiência que nossa prostituta-conselheira teria como meio de solucionar os problemas das iniciantes no ofício. Greda sugere que os problemas sexuais de Antônica eram fruto de sua inexperiência, que ela e seu "maridinho" aprenderiam a resolver com as "aulas práticas" de Greda. Na "difícil vida alegre", muitas prostitutas recorreram ao "Consultório feminino" em busca de solução para seus sofrimentos:

Ismenia — Li com grande emoção a sua narrativa.

Será possível que sofra tanto?

Espero minorar a sua situação. Já me apareceu um biquinho, mas não lhe convêm: - o de empregada da Candinha, rapariga mineira e que é bela horizontal na rua do Nuncio. 0 padre Amaro prometeu-me coisa melhor - 0 da menina engolir hóstias três vezes por semana atrás do altar mor (Pataka, 1916c: 7, grifo do autor).

0 conselho noticia a relação entre o clero católico e a prostituição, não pela ficção pornô-erótica, de tradição libertina, mas pelas redes sociais de Pataka, em que até os padres encontravam satisfação sexual. Pelo relatado, Ismenia deveria estar "pelas janelas", expressão para as prostitutas que não trabalhavam em algum prostíbulo estável, ficando sujeitas, assim, a violências constantes. Dessa maneira, Greda comove-se com o relato de dor de Ismenia e procura emprego para ela, como o fez com Atillia:

Atillia - Arranjei-Ihe uma excelente colocação: casa, comida magnífica (vinho ou cerveja nas refeições) completa tranquilidade de espírito, trabalho suavíssimo e $100 \$ 00$ ordenado. Exige apenas, abstinência de frutas indigestas e que minha amiguinha já saiba o que é o amor de mãe.

0 emprego é de ama de leite, uma verdadeira sinecura na época atual (Pataka, 1916c: 7).

Atillia era, provavelmente, uma profissional do sexo que engravidou e se encontrava desamparada. De novo o Rio Nu indica interferir na vida de seus leitores e leitoras, principalmente das leitoras prostitutas, mobilizando suas relações sociais e encontrando um emprego de acordo com a condição da menina na casa de uma distinta mãe de família. Desse modo, as vidas de duas mulheres tão afastadas socialmente se entrecruzavam pela intermediação direta do Rio Nu.

Não só profissionais do sexo recorriam às orientações da coluna. Mulheres casadas, solteiras, noivas e até mesmo senhoras de idade solicitavam ajuda. Isso porque "Consultório feminino" também era uma cartilha de comportamentos sexuais para mulheres. A educação sexual não foi um saber selecionado para a modernização da cidade e de sua gente como outros saberes científicos em vigor na modernização da cidade no início do século XX justa- 
mente pela moralidade católico-portuguesa instituída (Herschann et al., 1996). Sendo assim, como a "mulher moderna" poderia aprender e tirar suas dúvidas? A construção de uma sensibilidade erótica moderna foi um dos objetivos das potências pornô-eróticas da Primeira República, dessa forma, o Rio Nu, ao lançar o "Consultório Feminino", criou um espaço de educação sexual altamente transgressivo para a moralidade vigente - uma educação sexual pornô-erótica que tratava da sexualidade feminina.

Pataka respondia questões de uma variedade de tipos femininos: lascivas, experientes, ingênuas, virgens, celibatárias, namoradeiras, casadas, viúvas, jovens e senhoras de idade, entre outras. Virgindade, gravidez, técnicas de sedução, impotência masculina, diversas práticas sexuais, muitas significadas como "modernas", entre elas, acentuada presença do sexo anal, são fontes de curiosidades e dúvidas encaminhadas a Greda, aparecendo por vezes em minúcias. Para aquelas que tinham medo de perder a virgindade, a educadora sexual explicava: "Carlota - Desde que ele não seja bruto tudo se fará, sem haver muito derramamento de sangue. É certo que se torna preciso desbravar o caminho. Mas com certa coisa e jeito não há dificuldade que resista" (Pataka, 1916d: 6). Para as mulheres que tinham acabado de perder a virgindade e estavam aflitas com as consequências em seus corpos, a professora Greda explicava: "Adonzita - Isso não é propriamente assadura. A menina casou-se há três dias: é pois resultado das picadas de amor. Não tenha medo e vá deixando o bichinho picar" (Pataka, 1916c: 7). Senhoras de idade também apresentavam suas dúvidas. Queriam fazer sexo, mas tinham dificuldades inerentes à idade, e Pataka orientava: "Senhorinha — deite-se sempre de barriga pra cima, vire a cabeça para o lado esquerdo e deixe insensivelmente a natureza obrar. Experimente e veja que comodidade isso dá" (Pataka, n. 1.695, 1916g: 5). "Meninas de família" também escreviam para o "Consultório Feminino":

Menina de família - pede-nos com sinceridade o conselho? Cumpri-lo-á? Pois então ouça: abrace-se ao travesseiro e, pensando muito no seu queridinho, introduza de leve o dedo mindinho numa fenda que há de encontrar abaixo do ventre e então friccione. Dentre em pouco há de, maluquinha e vesga, verificar que isso é bom como o diabo (Pataka, 1916f: 3).

Aqui, a "prostituta-educadora" ensina a "menina de família" a se masturbar. Eis mais uma transgressão às performances de gênero femininas possibilitadas pelas potências pornô-eróticas. 0 que a moralidade social separou, as potências pornô-eróticas uniram: o encontro entre a cocote e a "menina honesta", possibilitando a experimentação de prazeres até então interditados à tal moça.

Por fim, destaco o encontro da tradição com a modernidade:

Cordelia Lea - Discordamos completamente. Por que razão há de um padre entrar na posse de seus segredos, conhecer os mistérios de sua alma? Na sua idade pouco se peca. Se tem amado 
muito, se tem sido amada igualmente, para que há de encher de inveja o pobre sacerdote que se custará a conter sentado no confessionário? Continue a amar, continue a ser feliz. 0 amor não é delito e se o é lembre-se das palavras com que Cristo fulminou os que apostrofavam Madalena: "Quem for isento de culpa que atire a primeira pedra..." (Pataka, 1916e: 7).

A condução narrativa apresenta a seguinte cena: uma senhora de idade envia uma carta a uma prostituta experiente que assinava uma coluna em um jornal considerado pornográfico. E mais: recorre procurando solução para o seu conflito existencial! Cordelia Lea é uma mulher ativa sexualmente, porém, pela descrição da resposta, sua vida sexual não era com o seu marido, o qual, talvez, não estivesse vivo. Ainda assim, sua vida sexual e amorosa não cessara. Ela encontrou uma forma de se manter sexualmente ativa, amando e sendo amada, desejando e sendo desejada, uma existência não vencida pelo tempo, mas sim "vivificante" ! Sua angústia relaciona-se com o social-histórico de sua época: seria pecado desfrutar do amor, dos prazeres sexuais, já que ela os encontrava fora de um relacionamento "abençoado" pela Igreja católica? Seria ela, segundo tal doutrina, uma pecadora da carne" ? Deveria, então, confessar-se ao padre? Aqui a modernidade pornô-erótica entra em ação. A professora-prostituta diz: não! Não é pecado sentir prazer sexual, não é pecado amar e ser amada, desejar e ser desejada. 0 padre não tem que doutrinar a sua vida, logo ele, um homem supostamente restrito pelo celibato, morreria de "inveja o pobre sacerdote que se custará a conter sentado no confessionário". Caso Cordelia Lea continuasse angustiada, Greda assegura à sua leitora que deve seguir o caminho e, para isso, apropria-se de um trecho bíblico, das palavras do próprio Messias: "Quem for isento de culpa que atire a primeira pedra...".

"Consultório Feminino": uma escrita pornô-erótica pedagógica e de orientação profissional, na qual uma suposta experiente e articulada profissional do sexo se transforma em educadora de uma feminilidade significada como "moderna". As potências pornô-eróticas de Pataka apresentam-se na alvorada da modernidade carioca com a presença-diferença da sexualidade feminina, seus medos e desejos. Mulheres de "família" e da "vida alegre", com larga experiência sexual e inexperientes, lascivas e virgens ingênuas, jovens e idosas tiveram a possibilidade de aprender com a "prostituta-educadora" possibilidades de criação de um novo feminino, não objetificado e maldito como o do pornô-erotismo masculino dominante, e sim ativo e vivificante!

\section{CONCLUSÃO}

s potências pornô-eróticas da Primeira República não foram compostas apenas da
discursividade masculina, sendo também potencializadas por escritas de verve feminina, entre elas, as de Germaine e Greda Pataka, o que exerceu efetiva diferença e impacto 
sócio-histórico. Afinal, se a construção de uma esfera pública de debate pela imprensa já é um acontecimento moderno, a presença de tal debate e publicidade por meio de uma imprensa pornô-erótica é um acontecimento que caracteriza o tipo de sensibilidade moderna do Rio de Janeiro finissecular - a Belle Époque imoral carioca. E mais: a conquista de espaço de escritas pornô-eróticas femininas no mercado editorial da cidade indica certas transformações nas performances tradicionais de gênero em um momento de desdobramento da primeira onda feminista, no qual a imprensa da capital do país se lançava em debates em torno dos comportamentos de gênero "corretos" ou "incorretos"; no "como" deveria ser essa mulher "moderna".

Por fim, as "escritas de revolta" de Germaine, a cortesã-cronista, e a "cartilha de educação sexual" de Greda Pataka, a prostituta-educadora, atuaram efetivamente na construção da sensibilidade erótica moderna por meio das dimensões sexuais femininas, transgressivas ao próprio pornô, no interior da ordem discursiva masculinista. Essa "nova mulher" teve a possibilidade de encontrar na imprensa de gênero alegre escritas de transformação do feminino. Pelo "como se" dessas ficções pornô-eróticas, muitas mulheres leitoras do Rio Nu e da Sans Dessous tiveram a possibilidade de se perceberem donas de seus desejos e corpos, de suas dores e delícias, potencializando comportamentos e sensações libertos dos tradicionais recato e pureza que aprisionavam (e ainda aprisionam) muitas mulheres. Suas lições atuaram na construção de um "moderno feminino vivificante".

\section{NOTAS}

1 Neste estudo, os termos eróticos e pornográficos são problematizados sem o julgamento moral que classifica um como sublime (erotismo) e outro como vulgar (pornografia); eles serão apresentados em suas potências no social-histórico da Primeira República.

2 Discurso aqui conforme Michel Foucault (2006). Não sendo apenas fala, mas acontecimentos praticados na sociedade, meio em que os poderes são legitimados e redistribuídos no corpo social por métodos microfísicos - "o discurso não é simplesmente aquilo que traduz as lutas ou os sistemas de dominação, mas aquilo porque, pelo que se luta, o poder do qual nos queremos apoderar" (Foucault, 2006: 10).

3 Alguns filósofos interessados em propagar as "luzes" reconheceram o sexo como uma potência, instaurando o problema pornô-erótico como uma arma de combate ao Antigo Regime: o iluminismo libertino, no qual a mulher entra em destaque, porém de forma objetificada, pois essa mulher é fruto da imaginação masculina (Darnton, 1996). 
4 Como um dos efeitos do surgimento do movimento feminista, o Oitocentos "Estereotipou essa mulher, conferindo-Ihe imagens reconhecíveis e diversas, porém praticamente intercambiáveis. Pintores e poetas reviveram e aprimoraram mulheres fatais do passado distante, dos mitos religiosos e das lendas históricas, ou então inventaram sua própria imagem de femme fatale [...]. A mulher perigosa veio a constituir-se num dos temas prediletos da criação literária e artística do século" (Gay, 1988: 150). A partir da segunda metade do século XIX, as femmes fatales proliferaram na imaginação de letrados e artistas, apresentando um importante aspecto desse imaginário que se desdobra pelo século XX: o medo da mulher que não se submete ao ordenamento social instituído. 0 feminino maldito é um dos efeitos do ativismo feminino em muitos homens (não em todos), os quais se sentiam ameaçados por essa nova feminilidade.

5 Para Zygmunt Bauman (1999: 23), “a ambivalência, possibilidade de conferir a um objeto ou evento mais de uma categoria, é uma desordem específica da linguagem, uma falha da função nomeadora (segregadora) que a linguagem deve desempenhar. 0 principal sintoma de desordem é o agudo desconforto que sentimos quando somos incapazes de ler adequadamente a situação e optar entre ações alternativas. É por causa da ansiedade que a acompanha e da consequente indecisão que experimentamos a ambivalência como desordem".

6 Belle Époque é o período entre o fim do século XIX e as primeiras décadas do século XX no qual havia uma celebração do modelo de sociedade ocidental capitalista da qual Paris seria a grande vitrine (Rodrigues, 1986).

7 Imaginário é aqui mobilizado com base em Cornélius Castoriadis (1982: 13): a "criação incessante e essencialmente indeterminada (social-histórica e psíquica) de figuras / formas / imagens, a partir das quais somente é possível falar-se de 'alguma coisa'. Aquilo que denominamos 'realidade' e 'racionalidade' são seus produtos".

8 "Como se" refere-se ao terceiro ato de fingir do processo de leitura de um texto ficcional apresentado por Wolfgang Iser, o qual instaura efeitos no leitor. Este se irrealiza para experimentar o imaginário figurado pelo texto fictício: "A representabilidade daquilo que é provocado pelo como se significa que nossas capacidades se põem a serviço desta irrealidade para, no processo de irrealização, transformá-la em realidade" (Iser, 2013: 48). 0 leitor, ao experimentar o imaginário pela ficção, procura, de forma ativa, sanar tal tensão ao reconduzir o acontecimento do imaginário a um sentido que lhe seja conhecido. É nesse momento que se instaura o sentido do texto fictício pelo processo de semantização. Essa transgressão que o "como se" promove no leitor, a transgressão de si mesmo por sua irrealização, é assimilada 
por tal busca. Daí a diversidade de "sentidos" que um texto ficcional pode possibilitar pela tríade real, imaginário e fictício, sendo essa sua condição de existência.

9 Para Michel Certeau (2008: 76-77), "local de fala" é o espaço em que o texto está sendo edificado, o qual exerce forte interferência no que se produz e determina as regras de quem pode produzir.

10 Para Foucault (2009: 98), enunciado é: "uma função de existência que pertence, exclusivamente, aos signos, e a partir da qual se pode decidir, em seguida, pela análise ou pela intuição se eles 'fazem sentido' ou não, segundo que regra se sucedem ou se justapõem, de que são signos, e que espécie de ato se encontra realizado por sua formulação [...] não é em si mesmo uma unidade, mas sim uma função que cruza um domínio de estruturas e de unidades possíveis e que faz com que apareçam, com conteúdo concretos, no tempo e no espaço".

11 Judith Butler (2016) argumenta que gênero é uma performance, e não uma essência preestabelecida. 0 "verdadeiro sexo" (como ironiza Foucault) e o gênero podem ser entendidos como uma ficção social que, para funcionar, precisa ser repetida constantemente, de modo que garanta sua força reguladora dos papéis sociais femininos e masculinos. As constantes repetições das performances de gênero fundam e consolidam o sujeito. Embora exercida individualmente, tais ações são coletivas e temporais, objetivam a reprodução compulsória da heteronormatividade. Desse ponto de vista, os gêneros não são nem naturais, nem estáveis; são constituídos no tempo e no espaço.

12 Sobre a relação entre a imprensa carioca e a construção de uma sensibilidade moderna, Mônica Pimenta Velloso (2006: 2) afirma que "as revistas apresentam-se como órgão de ponta na construção, veiculação e difusão do ideário moderno. São elas que ajudam a forjar a moderna sensibilidade brasileira, abrindo-se para diferentes leituras e sentidos".

13 Mobilizamos a diferenciação entre modernidade (momento histórico), modernização (edificação socioeconômica do moderno) e modernismo (projetos culturais que recriam os usos simbólicos com um apelo experimental e/ou crítico) de Nestor Canclini (2003).

14 Termo "criado por Alexandre Dumas Filho, autor da Dama das Camélias e amante de Marie Duplissis, que nela se inspirou para caracterizar o mundo no qual circulavam mulheres que não eram nem prostitutas nem senhoras" (Menezes, 2007: 89). Termo que entrou para o vocabulário pornô-erótico do Rio de Janeiro com a inauguração do Alcazar Lírico no centro da cidade, em meados do século XIX, que trouxe "uma nova personagem urbana: a cocotte comédienne do teatro ligeiro e das operetas; atriz-cortesã da modernidade oitocentista" (Menezes, 2007: 77). 
15 A crônica foi um gênero difundido pela modernização da imprensa. Com a aceleração da vida moderna e o impacto de técnicas como a fotografia, não havia mais tempo para extensos e complexos artigos literários dos jornais de então. Estes foram substituídos pelos textos ágeis dos modernos cronistas, como João do Rio, Medeiros e Albuquerque e Humberto Campos (Velloso, 2010).

16 A gentrificação "consiste em uma série de melhorias físicas ou materiais e mudanças imateriais - econômicas, sociais e culturais - que ocorrem em alguns centros urbanos antigos, os quais experimentam uma apreciável elevação de seu status" (Bataller e Botelho, 2012: 10). A gentrificação também se caracteriza por uma transformação no perfil social dos centros gentrificados, isto é, com a valorização socioeconômica do espaço, as camadas economicamente abastadas deslocam as camadas populares que ali moravam. A gentrificação é, assim, uma "expressão espacial de uma profunda mudança social" (Bataller e Botelho, 2012: 10).

17 "Institui instituindo" é um termo de Castoriadis (1982) para o qual as sociedades e os seres humanos são feitos no e pelo imaginário. Cada sociedade se "institui instituindo" um magma de significações imaginárias sociais, ou seja, se faz fazendo seu modo de existência no mundo. Como não tem uma estrutura determinada e definitiva, e sim magmática, em seu fazer cada sociedade se abre às possibilidades de transformação.

18 Para a construção teórico-metodológica do "feminino gentrificado", além dos atos de fingir de Wolfgang Iser (que articulam imaginário, real e ficção), é fundamental também as contribuições da chamada geografia de gênero, a qual "tem por objetivo principal a análise das relações entre espaço e gênero nas suas formas mais variadas, e nos papéis e funções que homens e mulheres ocupam nestas" (Borghi, 2015: 134). Sobre tipos ficcionais femininos atuantes na produção pornô-erótica do período, ver: Carvalho, 2018; 2020.

190 High Life Club ficava na Rua Santo Amaro, n²8, Glória, Rio de Janeiro, de posse do empresário italiano Pascoal Segreto (proprietário de grande parte dos novos lazeres urbanos da cidade), sendo um elegante teatro, café-concerto, onde ocorriam famosos bailes de carnaval (Gomes, 1989).

20 Vieux marcheur é um dos tipos da cidade encontrado na produção pornô-erótica do período, apresentado pelo pornô-erotismo masculino como um tolo que faz todas as vontades das cocotes (Carvalho, 2018).

21 Sexo frágil, instinto materno e recato são construções discursivas em torno da natureza da mulher branca ocidental instaurada pelo iluminismo, o qual constrói um novo modelo de diferença biológica entre homens e mulheres. Estas seriam movidas não por sua racionalidade, e sim pelo imperativo de seu órgão sexual. Já as mulheres não brancas não se encaixam 
em tal discursividade, pois a divisão racista da humanidade instaurada pela modernidade classifica-as como inferiores, diminuindo sua humanidade, tornando-as suscetíveis à exploração constante de seus corpos. Dessa forma, o "recato" é uma condição para a construção de uma feminilidade "correta" impostas às mulheres brancas, que deveriam aceitar se submeter primeiro ao pai, depois ao marido, de forma hierarquizada e virilista. Série de longa duração que se instaura nos Setecentos e cujos efeitos ainda normatizam as sociedades ocidentais (Carvalho, 2018: 31-42).

22 Suzana Castera era uma presença constante nas potências pornô-eróticas masculinas, chegando mesmo a ter seu nome estampado no Rio Nu como uma de suas colaboradoras. Na Sans Dessous, ela materializou o refinamento do feminino gentrificado e ganhou até uma homenagem na coluna "Leurs Minoir" (Carvalho, 2018).

230 dandismo sociocultural aparece nos jornais de gênero alegre por meio de fotografias e comentários sobre chás, festas e jantares em rendez-vous famosos da Belle Époque imoral carioca, celebrando momentos de lazer refinados e erotizados. Para Ângela Reis (2013), o dandismo da época presentifica-se pelo desencanto com a sociedade burguesa do fim do século, no qual a reinterpretação de Baudelaire possibilitou uma performance que combinava rebeldia e refinamento estético. 0 dandismo tornou-se "um dos traços do movimento decadentista, que se disseminou no Brasil com o advento da República, em 1889, a partir da qual se buscou afirmar uma imagem de modernidade no país, divulgando para os países civilizados uma visão ilustre e respeitável da sociedade brasileira" (Reis, 2013: 35).

24 "Semblante" aqui compreendido como a imagem que fazemos de nós mesmos, a construção de nossa persona social, nas palavras de Goffman (1977 apud Haroche, 2008: 154), "0 semblante que carregamos, assim como o dos outros, são construções de uma mesma ordem, determinadas pelas regras do grupo e a definição da situação".

25 A literatura pornô-erótica feminina francesa decadentista invertendo esquemas tradicionais do pornô-erotismo moderno, colocando em xeque a superioridade e o domínio dos homens em relação às mulheres. Apresenta também uma contrapartida à "demonificação" do feminino decadentista: a aversão ao masculino, instaurando a lesbianidade como forma de rompimento aos dispositivos heteronormativos, invertendo os jogos de poder característicos do pornô-erotismo francês masculino; ao mesmo tempo cria o seu avesso: o "maldito masculino". Característica também presente na escrita pornô-erótica de Cecília Bandeira de Melo Rebelo de Vasconcelos (Carvalho, 2018: 127-133; 161-164; Frappier-Mazur, 1988). 


\section{REFERÊNCIAS BIBLIOGRÁFICAS}

BATALLER, M. A. S.; BOTELHO, M. L. 0 estudo da gentrificação. Continentes, Rio de Janeiro, ano 1, n. 1, p. 9-37, 2012.

BAUMAN, Z. Modernidade e ambivalência. Tradução: Marcus Penchel. Rio de Janeiro: Jorge Zahar, 1999.

BORGHI, R. O espaço à época do queer: contaminações queer na geografia francesa. Revista Latino-Americana de Geografia e Gênero, Ponta Grossa, v. 6, n. 2, 2015.

BUTLER, J. Problemas de gênero: feminismo e subversão da identidade. 11. ed. Rio de Janeiro: Civilização Brasileira, 2016.

CANCLINI, N. G. Culturas híbridas: estratégias para entrar e sair da modernidade. 4. ed. São Paulo: EDUSP, 2003.

CARVALHO, M. V. de. Leituras do prazer: a criação pornô-erótica na alvorada da modernidade carioca. Tese (Doutorado) - Universidade do Estado do Rio de Janeiro, Rio de Janeiro, 2018.

CARVALHO, M. V. de. Mulher negra na arena pornô-erótica do pós-abolição carioca: embates entre o feminino gentrificado do Rio Nu e o feminino vivificante de Gilka Machado. Canoa do Tempo, Amazonas, v. 12, n. 1, 2020. No prelo.

CASTORIADIS, C. A instituição imaginária da sociedade. Rio de Janeiro: Paz e Terra, 1982.

CERTEAU, M. A escrita da história. Rio de Janeiro: Forense Universitária, 2008.

CONCURSO de Beleza. Sans Dessous, Rio de Janeiro, ano I, n. 3, p. 16, 1909.

DARNTON, R. Sexo dá o que pensar. In: NOVAES, A. (org.). Libertinos e Libertários. São Paulo: Companhia das Letras, 1996. p. 21-42.

DEALTRY, G. O Fio da Navalha: malandragem na literatura e no samba. Rio de Janeiro: Casa da Palavra, 2009.

FERREIRA, A. S. Sexualidade à brasileira: as imagens eróticas no jornal O Rio Nu - 1900-1916. In: REBLIN, I. A.; RODRIGUES, M. dos S. Arte sequencial em Perspectiva Multidisciplinar. Minas Gerais: Aspas, 2015. p. 119-131.

FOUCAULT, M. A arqueologia do saber. 7. ed. Rio de Janeiro: Forense Universitária, 2009.

FOUCAULT, M. A ordem do discurso. São Paulo: Loyola, 2006.

FRAPPIER-MAZUR, L. Convention et subversion dans le roman érotique féminin (1799-1901). Romantisme, Lyon, n. 59, p. 107-119, 1988. https://doi.org/10.3406/roman. 1988.5480

GAY, P. A experiência burguesa da Rainha Vitória a Freud: a educação dos sentidos. São Paulo: Companhia das Letras, 1988.

GERMAINE. Carnet de uma mundana. Sans Dessous, Rio de Janeiro, ano I, n. 14, p. 16, 1910a.

GERMAINE. Carnet de uma mundana. Sans Dessous, Rio de Janeiro, ano I, n. 17, p. 14, 1910 b.

GERMAINE. Carnet de uma mundana. Sans Dessous, Rio de Janeiro, ano I, n. 19, p. 14, 1910c. 
GOMES, D. Antigos Cafés do Rio de Janeiro. Rio de Janeiro: Kosmos, 1989.

GREEN, J. N. O joelho de Sarah Bernhardt: negociando a "respeitabilidade" feminina no palco carioca, 188019101. Escritos, Rio de Janeiro, n. 8, 2004.

HAROCHE, C. A condição sensível. Rio de Janeiro: Contracapa, 2008.

HERSCHANN, M.; KROPF, S.; NUNES, C. Missionários do progresso: médicos, engenheiros e educadores no RJ-1870/1937. 10. ed. Rio de Janeiro: Diadorim, 1996.

HIGH Life Club. Carnaval de 1910. Sans Dessous, Rio de Janeiro, ano I, n. 17, p. 11, 1910 b.

HUNT, L. (org.). A invenção da pornografia: a obscenidade e as origens da modernidade, 1500-1800. São Paulo: Hedra, 1999.

ISER, W. O Fictício e o Imaginário: perspectivas de uma antropologia literária. Rio de Janeiro: EdUerj, 2013.

MENEZES, L. de M. (Re)inventando a noite: o Alcazar Lyrique e a cocotte comedienne no Rio de Janeiro Oitocentista. Revista Rio de Janeiro, Rio de Janeiro, n. 20-21, p. 73-91, 2007.

OLIVEIRA, C. de. As Pérfidas Salomés: o ideal feminino e a representação da mulher urbana nas ilustradas Fon-Fon! e Para Todos - 1900-1930. In: ENCONTRO ANUAL DA ANPOCS, XXIX, 25-29 out. 2005, Caxambu, MG. Anais [...], São Paulo, 2005. 28 p.

PATAKA, G. Consultório Feminino. Rio Nu, Rio de Janeiro, n. 1.697, p. 2, 1916a.

PATAKA, G. Consultório Feminino. Rio Nu, Rio de Janeiro, n. 1.699, p. 3, $1916 \mathrm{~b}$.

PATAKA, G. Consultório Feminino. Rio Nu, Rio de Janeiro, n. 1.700, p. 7, 1916c.

PATAKA, G. Consultório Feminino. Rio Nu, Rio de Janeiro, n. 1.710, p. 6, 1916d.

PATAKA, G. Consultório Feminino. Rio Nu, Rio de Janeiro, n. 1.718, p. 7, 1916e.

PATAKA, G. Consultório Feminino. Rio Nu, Rio de Janeiro, n. 1.719, p. 3, $1916 f$.

PATAKA, G. Consultório Feminino. Rio Nu, Rio de Janeiro, n. 1.695, p. 5, $1916 \mathrm{~g}$.

REIS, Â. de C. Contexto social, atuação e imagem pública de uma atriz no teatro brasileiro na virada do século XIX: Cinira Polonio. Revista Urdimento, Santa Catarina, v. 2, n. 21, 2013. https://doi. org/10.5965/1414573102212013032

RODRIGUES, A. E. R. O Rio de Janeiro da Bela Época - História e Cultura na passagem do século XIX ao século XX. Tese (Livre-Docência) - Universidade do Estado do Rio de Janeiro, Rio de Janeiro, 1986.

VELLOSO, M. P. As modernas sensibilidades brasileiras: uma leitura das revistas literárias e de humor na Primeira República. Revista Nuevo Mundo, México, 28 jan. 2006. https://doi.org/10.4000/nuevomundo.1500

VELLOSO, M. P. História e Modernismo. Belo Horizonte: Autêntica, 2010. 